Exclusions and Alternative Provision: Piecing Together the Picture

Andrew Malcolm

Applied Social Studies, University of Bedfordshire, Luton, UK

andrew.malcolm@beds.ac.uk

ODCID ID: orcid.org/0000-0002-8137-8122 


\section{Exclusions and Alternative Provision: Piecing Together the Picture}

This article makes the case for clearer reporting of alternative provision. The main body of this paper consists of an analysis of available data on permanent exclusions and attendance at alternative provision. Findings show a greater number of young people attending alternative provision compared to those permanently excluded and concerning patterns of over representation among children in care and those with a special educational need or disability. This raises issues of children's rights, particularly equality of educational experience and of fair access to the schooling system. It is argued that annual reporting on exclusions should be developed to include a section of in depth reporting on alternative provision.

Keywords: alternative provision; exclusion; children in care; special educational needs; risk ratio 


\section{Introduction}

This paper will follow the government definition of alternative provision (AP) as 'an organisation where pupils engage in timetabled, educational activities away from school and school staff' (Taylor, 2012, p4). Alternative provision is attended by pupils who are excluded formally from mainstream education and those directed off site to improve their behaviour essentially informal exclusion given the current lack of reporting on this area. Alternative provision includes pupil referral units (PRUs), alternative provision academies, alternative provision free schools and a vast range of other organisations which provide schooling away from the mainstream site. Attending alternative educational provision is rarely if ever the choice of the pupil or of their parents/carers (Gazeley, 2010 and Thomson \& Pennacchia, 2015). Those who attend alternative provision have been placed there by either their local authority or school for a variety of official reasons as set out in the statutory guidance which refers to AP as:

education arranged by local authorities for pupils who, because of exclusion, illness or other reasons, would not otherwise receive suitable education; education arranged by schools for pupils on a fixed period exclusion; and pupils being directed by schools to off-site provision to improve their behaviour (DfE, 2013, p3 - Alternative Provision: Statutory guidance for local authorities)

Almost half of the pupils in alternative provision have been or are at risk of exclusion from school (DSCF, 2008). Other pupils include those with medical needs, both physical and emotional, those unable to cope in mainstream school (including school refusers) and children temporarily without a school place (DCSF, 2008). In addition to this diversity of needs there is a gender skew with boys making up $73 \%$ of pupils in alternative provision as 
of January 2016 (DfE, 2016e). Pupils are twice as likely as the average school pupil to qualify for free school meals (FSM) and are more likely to be known to social services, the police and to have had poor attendance in school (Taylor, 2012).

Children and young people with special educational needs (SEN), those who have experienced local authority care, and those from specific cultural backgrounds (Travellers of Irish heritage, Gypsy/Roma and Black Caribbean) are significantly over-represented in alternative provision schooling (Malcolm, 2015). Parsons (1999), drawing on Ofsted and National Foundation for Educational Research (NFER) reports and the work of Hayden, discusses other experiences common to pupils excluded from mainstream as including: family breakdown, multiple moves/disruption, bereavement, disability, violence/abuse, major accidents/incidents, previous serious exclusion, poor basic skills, peer pressure, limited aspirations/opportunities, poor relationships, bullying and dissatisfaction with the curriculum. Parsons notes that these will present major difficulties as young people attempt to cope with life.

The position of the Department for Education (DfE) in the recent White Paper (DfE, 2016a) is that 'by every objective measure, pupils who have spent time in alternative provision (AP) do considerably worse than their peers' (DfE, 2016a, p102). This is based on the KS4 qualifications data for those completing their school careers in AP and on progress data which considers success as a stable education, employment or training place for two terms after leaving school. These are obviously important measures but are arguably focused on the short term. Indeed, there is a paucity of research data on longitudinal outcomes for young people who attend alternative provision (Thomson \& Pennacchia, 2015) so it is hard to interrogate the claim referenced above. The researcher has however presented data elsewhere 
which provides longer term evidence suggesting the potential for a positive role for alternative provision (Malcolm, 2015).

The literature relating to alternative provision includes numerous studies of specific projects (for example, Cook 2005, McLoughlin 2010, Meo \& Parker 2006, de Castella 2011, Barrow 2000, Cullen \& Monroe 2010, Malberg 2008). There are many scoping studies undertaken by, or on behalf of government (Ofsted 2004, 2011, 2013 \& 2014, Kendall et al., 2003 \& 2007, Thompson \& Russell 2007, McCluskey et al., 2013). There are government strategies, guidance and reports on pilot projects (DCSF 2008, White et al. 2012, Taylor 2012, DfE 2013, Clay and Thomas 2014). There is also the beginnings of literature on specific issues in alternative provision such as Gender (Russell and Thomson, 2011) the lack of consistent monitoring (Thomson and Russell, 2009) and recommendations for reducing shortcomings and better practice (Riley et al., 2006; Gazeley et al., 2013; McCluskey et al., 2015 and Thomson \& Pennacchia, 2015).

Alternative provision schooling is an important part of the education system. Given the characteristics of pupils, the experiences they are more likely to have had, and the destinations and the outcomes they are more likely than the average young person to experience there is a moral imperative to ensure that the nature and usage of alternative provision is reported as clearly as possible to enable effective scrutiny to take place. This is also a legal issue and a matter of individual rights, an issue of equality, of fair access to the schooling system and to education. This is particularly important given the significant overrepresentation of children in care $(\mathrm{CiC})$ within alternative provision settings - this is presented and discussed later. 


\section{Method}

The majority of the data below are compiled from two annual central government publications - 'Schools, Pupils and their Characteristics' (SPC), and 'Permanent and fixedperiod exclusions in England' (PFPEE). Tables 1b, 3a, 4a are used in the former and tables $1,3,7,8 \mathrm{~b}, 9,11,13$ in the latter (these are the table references for the 2014 and 2013/14 publications respectively), in addition table S1 was used from the 2016 edition of 'Schools, Pupils and their Characteristics' provided historical data for numbers of pupils with SEN in schools and pupil referral units. Children in care are not covered in these publications. Data relating to the exclusion of children in care are published in 'Outcomes for children looked after by local authorities in England' (OCLALAE) but there is no publication which gives the number of children in care who attend alternative provision settings. This data was accessed through a freedom of information request to the DfE.

As with any official statistics there will be limitations to these sources because they are gathered by multiple individuals and without the express purpose of this research in mind. Particular issues with exclusion statistics include discrepancies between sources (Smith, 2009) unofficial exclusions and under-reporting (Parsons, 2008). Despite this the value of official statistics is well established (Gorard, 2003) and these sources have been used for similar research projects (Parsons, 2008).

The results are in two parts. The first part unpicks the extent to which pupils are being directed into alternative provision settings by their head teachers, the second explores differential levels of over-representation in permanent exclusion (PEx) and AP attendance for certain groups of pupils. 


\section{Selecting characteristics for detailed analysis}

The criteria used to select characteristics of pupils significantly over-represented in the data was to compare exclusion and population statistics for the available demographics. This was undertaken on the data relating to the academic year 2013/14 as this was the most recent year for which the data were available when undertaking this research. Groups were considered over-represented if their rate of exclusion was double or greater than that of the whole school population. The pupil characteristics selected for detailed analysis were pupils in receipt of free school meals, those from Traveller of Irish Heritage, Gypsy / Roma, White and Black Caribbean, and Black Caribbean ethnic backgrounds, pupils with SEN both with and without a statement or Education and Health Care (EHC) plan, and Children in Care.

Those familiar with exclusion and alternative provision may be surprised that being male does not get flagged up as an over-represented group. It is true that roughly four out of five pupils who are permanently excluded are boys and between 70 and 75 per cent of the alternative provision population are male. However, when comparing the exclusion rate from $2013 / 14$ for all boys $(0.10 \%)$ with the of the whole school population $(0.06 \%)$ the criteria set out above are not met.

Indeed, the selection criteria outlined above suggest that pupils aged 12, 13 and 14 should also be included as over-represented groups. However the available data is not consistently broken down by ages so as to allow for comparisons of over-representation between PEx and AP population groups. This does however point to questions about the nature of this stage of secondary schooling — questions which are not within the scope of this article.

\section{Detailed analysis}


To bring simplicity and stability to the data the average annual number of PEx and AP attendees over the three years was used. This means anomalous results are not taken out of their broader context and the reader does not have to consider multiple years of data for this to be achieved. The most recent exclusions data when researching this paper related to the academic year 2013/14 and as such the analysis of over-representation covers the three years $2011 / 12$ to $2013 / 14$.

Percentages of exclusions and population make-up are presented before being brought together into the rate of over-exclusion and over-representation in the PRU and AP populations ${ }^{1}$. The significance of divergent rates of over-representation in PEx and AP is explored in the discussion later, in essence it points to increased likelihood for some groups to be directed off-site for their education by their head teacher.

A slight modification of the 'risk ratio' set out by Bollmer et al. (2007) is used to calculate over-representation $^{2}$. This gives the average risk of a particular outcome for members of a group relative to the risk for all students and is also in line with the approach taken by Parsons (2008). This involved taking the percentage of pupils from each characteristic group and dividing by the percentage of all pupils who experienced permanent exclusion or placement into a PRU or AP setting.

\section{Results}

The table below shows pupils attending AP settings over the six years 2011-2016. This begins to show the extent to which head teachers are directing pupils off-site into alternative

\footnotetext{
${ }^{1}$ The author would be happy to share the fuller collation of evidence upon request.

${ }^{2}$ The denominator used is 'all pupils' rather than 'all other pupils'.
} 
provision $^{3}$.

[Table 1 here]

As can be seen from the above there are around 45,000 pupils attending AP settings in any year. This includes 'dual registered' pupils whose main registration is elsewhere - in all likelihood this will be a mainstream school. Given the focus of this section is to consider the direction of pupils into off-site AP by their head teachers this is considered entirely appropriate $^{4}$. The last two columns show permanent exclusions and fixed term exclusions of six or more days, these are two of the routes by which pupils can end up in AP. As discussed in the introduction the other routes are placement by the relevant local authority (LA) for 'medical or other reasons' and placement by their head teacher 'to improve their behaviour'. The only other group to be considered is pupils permanently excluded in previous years who remain out of mainstream and in AP. A relatively robust estimate of the upper limit of the total number this group could represent is included in the table below ${ }^{5}$.

[Table 2 here]

The averaged figures show that well over half of the pupils attending AP are either placed by their LA for 'medical or other reasons' or are directed off-site to improve their behaviour by their head teacher. There are no official figures available for the numbers of pupils placed by their local authority for medical or other reasons but the limited evidence available to the author would suggest that use of AP by local authorities for these reasons would only be a minority of the 26,870 pupils identified above (Malcolm, 2015 and Terry \& Walls, 2014). As such it is the contention of this paper that significant use is being made by head teachers of

\footnotetext{
${ }^{3}$ Exclusions data for 2015 were not available at the time of writing.

${ }^{4}$ Indeed, the number of dual registered pupils is a footnote within each year's statistical release - highlighting the opacity of reporting on the use of AP.

${ }^{5}$ This was calculated by assuming all pupils start in mainstream school in year seven and that no permanently excluded pupils return to mainstream. The former assumption would likely lead to a slight under estimate the latter to a likely over estimate. The average number of exclusions by year group was taken over the years 2011-2015 and then used to calculate the additional numbers of pupils who could still be in AP because of exclusions in previous years, i.e. pupils PEx in year groups 7-10 in the previous year, those PEx in year groups 79 the year before that, et cetera.
} 
their power to direct pupils off the mainstream site to improve behaviour.

From the table above it seems probable that for every pupil permanently excluded another five are being placed into AP. This is not something that is tracked in any detail and given that neither child or parent gets a say in whether an AP placement goes ahead, feels somewhat similar in nature to 'unofficial exclusions' which are illegal (Office for the Children's Commissioner, 2012). Given the level of clarity with which exclusions are reported it would seem eminently sensible for the use of AP to be tracked in similar detail. Some of the dynamics of this extensive use of AP by head teachers are explored in the tables below.

[Table 3 here]

The implications of these data are in some ways simple, if you are poor, of certain ethnicity, in the care of your local authority or if you experience and learn about the world in a way which deviates from the normative experience you are significantly more likely to find yourself marginalised and excluded from mainstream schooling. These are all issues which have been considered in detail in the existing literature on exclusion (Paget et al., 2015; Watling, 2004; Parsons, 1999; Youdell, 2003; D’Arcy 2014; and Office for the Children's Commissioner, 2012). Given that a higher proportion of all these groups experience PEx than the average for all pupils it is not surprising that they are also all present in the alternative provision population at a higher rate.

What is important is that the way in which alternative provision is used is opaque particularly when compared to the research and policy ${ }^{6}$ focus on exclusions and the reporting that has emerged from this. Given the far more significant use of AP when compared to numbers of

\footnotetext{
${ }^{6}$ For example the commitment by New Labour to reduce permanent exclusions by a third.
} 
pupils permanently excluded in any year it would be timely to introduce more accountability into the use of alternative provision, this would ideally be on a number of levels (school, local authority and national reporting). Beyond the over-representation of particular groups of pupils in the AP population the difference when compared with rates of exclusion highlights some interesting dynamics which are shown in the next table and discussed below.

[Table 4 here]

As mentioned above the level of difference between rates of over-representation when comparing across PEx and AP population figures allow for the exploration of the dynamics within groups of pupils who are directed off the mainstream site by their head teachers. The groups for whom this difference is most significant are pupils in receipt of free school meals, those of either mixed White and Black Caribbean or Black Caribbean ethnicity, pupils with a statement (or EHC plan) of SEN and children in local authority care.

Pupils with a statement (or EHC plan) of SEN and children in local authority care are both over-represented to a greater extent in the alternative provision population than in permanent exclusion statistics. This pattern is concerning for both groups but particularly so for children in care who are just over twice as likely as the average pupil to be permanently excluded but over 2011/12 - 2013/14 were represented in the AP population at over 29 times the rate they are in the whole school population. Consideration of the actual numbers of pupils involved only serves to highlight the extreme nature of this disparity. Over the years 2011/12 through 2013/14 the average rate of exclusion and total number of children in care matched to the school census data means that on average 37 children in care were excluded from school. A response to a freedom of information request to the DfE which matched PRU and AP census data with children in care data showed the average total number of children in care attending alternative provision settings was 4,422 . Answers as to why such an extreme disparity exists 
are explored below.

\section{Discussion}

The discussion will focus on the lower rate of placement into AP (when compared to the rate of PEx) experienced by pupils in receipt of free school meals and those of mixed White and Black Caribbean and Black Caribbean ethnicity and on the higher rate of AP placement experienced by pupils with SEN (particularly those with a statement or EHC plan) and Children in Care. The rates of over-representation in AP placement and PEx for Travellers of Irish Heritage and Gypsy / Roma pupils do not diverge and as such there are no dynamics to discuss. It will suffice to point out that, apart from the significant rate of AP placement that $\mathrm{CiC}$ experience (discussed later), pupils from these backgrounds experience PEx and AP placement at a more significant rate than other marginalised pupils. As such there is far more work to be done in relation to understanding, engaging with and improving the educational experiences of pupils from these backgrounds.

Pupils in receipt of free school meals and those of mixed White and Black Caribbean or Black Caribbean ethnicity are somewhat less likely to end up in alternative provision than they are to be permanently excluded. This would seem to suggest that either when they are excluded they are more likely to experience a managed move ${ }^{7}$ into another mainstream school, that they are less likely than other groups to be directed off-site (into alternative provision) to improve their behaviour, or that once excluded they are dropping out of schooling altogether.

The issues of managed moves and going missing from education are beyond the remit of the

\footnotetext{
${ }^{7}$ Managed moves involve a pupil being transferred from the roll of one school to another, this must be undertaken with the agreement of their parents.
} 
data presented in this article. Both flag up opportunities for future research and important areas for policy development. Whilst the author is aware of a range of research exploring the use and experience of 'managed moves' there is little to no research on how commonplace managed moves are between schools. Given the extent to which pupils are being directed off site highlighted within this article, it would be timely for an exploration of the systemic use of managed moves. There has been some exploration of systemic issues around pupils going missing from the school system (Visser et al., 2005) which suggests this effects in the region of 100,000 pupils in any year. However, to date little progress has been made with 'addressing the educational reasons why some children and young people go missing' (Visser, J. et al., 2005, p52).

Whilst it is arguable that truancy and the related issues of exclusion, going missing, managed moves and direction off the school site are intrinsically connected to compulsory schooling such as to be called 'two faces of the same coin' (Gleeson, 1992, p438) this does not mean that understanding of these issues and policy development in these areas are not realistic goals. Indeed a focus on the complex dynamics of both inclusion and exclusion is recognised as the most appropriate route to developing inclusive practice (Clark et al., 1999).

In relation to children in care and pupils with SEN, particularly those with a statement or EHC plan, it is thought that something similar to the unintended consequences of the 'New Labour' policy to reduce exclusions by a third has led to this dramatic over-representation in the AP population (Malcolm, 2015). The guidance provided for head teachers when undertaking exclusions states they 'should, as far as possible, avoid excluding permanently any pupil with a statement of SEN or a looked after child' (DfE, 2012, p7). Despite this guidance both pupils with statements and looked after children are excluded at over twice the 
average rate of permanent exclusion. Nevertheless, there would seem to be a general consensus that educational issues for these pupils while not being sorted are perhaps in hand:

There has been a steady decline over the last 5 years in the rate of permanent exclusions and the rate for those with a statement of SEN has fallen more than the rate for all pupils (DfE, 2016b, p4).

And

$0.13 \%$ of looked after children have been permanently excluded - this is broadly stable following a period of decline in recent years (DfE, 2016c, p1).

Yet as has been seen above this improved rate of permanent exclusion is simply supplanted by a higher rate of placement into alternative provision schooling and extremely so in relation to children in care. So just as when 'New Labour' brought down the number of pupils experiencing permanent exclusion the number attending PRUs grew (Malcolm, 2015), guidance from central government to avoid the permanent exclusion of looked after children and pupils with a statement of SEN has led to the desired decline in these numbers but also to a far higher rate of placement into alternative provision for both of these groups.

This argument is strengthened by considering the data in Table 5 where exclusion statistics for 'children in need' are placed alongside those for 'children looked after' and for pupils with SEN without a statement alongside those for pupils with a statement of SEN. This is data for the 2013/14 school year.

[Table 5 here] 
Here it can be seen that although looked after children and those with a statement of SEN are less likely to experience permanent exclusion than pupils with similar experiences who do not fit these categories (children in need and pupils with SEN without a statement respectively) they are more likely, and far more likely in the case of looked after children, to experience at least one fixed period exclusion.

The adherence to guidance from central government has led to the marginalisation and essentially exclusion from mainstream of looked after children and those with a statement of SEN into alternative provision. This is a process which is at best opaque in the level of monitoring and reporting it undergoes. This lack of clarity poses challenges to those exploring the complex dynamics which shape the provision of successful care and education placements. Insufficient accountability creates a context where a reduction of hours in educational placement and the consequent impact on both care placement dynamics ${ }^{8}$ and a child's right to education goes largely unreported. The pressing need for accountability in, and reporting of, the extent and use of alternative provision schooling is made clear.

The above discussion of the extent to which alternative provision is used, particularly for some groups of pupils, raises issues in relation to inclusion. At this point it must be noted that any serious discussion of how schools can be inclusive must recognise complex dynamics of inclusion and exclusion which will be present in any school (Clark et al., 1999). As such it is perhaps most pertinent to ask the question, 'inclusion into what?' (Lindsay, 2007, p17). This is how the complex dynamics between inclusion and exclusion can be reconciled, by recognising that AP can play a positive role in a young person's educational experience that for some young people attending AP can be a far more inclusive and positive period of

\footnotetext{
${ }^{8}$ For example the need for foster carers to be available during school hours
} 
schooling than anything they had previously experienced (Malcolm 2015). It is where groups of pupils are significantly disproportionately represented in AP that the author would see things differently in particular for looked after children. At a time when much of what has previously been stable in a young person's life has changed school can provide a point of consistency. Indeed stability is understood to be a protective factor in life experiences of looked after children (Berridge, 2017). As such, it is important to challenge head teachers to do more to keep children in care in a stable placement in mainstream school and to target bringing down the level of over-representation of children in care in AP settings from where it currently sits at over 29 times the rate for all pupils.

This is not a value judgement of the kind of education pupils receive in alternative provision these arguments are outside of the scope of the current article and the author has elsewhere shown a positive role for AP (Malcolm, 2105). However, given the DfE position that 'by every objective measure, pupils who have spent time in alternative provision (AP) do considerably worse than their peers' (DfE, 2016a, p102) it is thought that the suggestion for clear and consistent annual reporting on alternative provision should be met with enthusiasm. Alternative provision can be helpful and is at times the most appropriate intervention but to fully understand these dynamics requires underpinning evidence about where pupils are actually being educated. The analysis in this article provides a starting point towards this but there is more to be done.

\section{Conclusion}

The data presented in this article has shown that a significant number of pupils are receiving their schooling in alternative provision settings each year because they have been placed by their local authority for 'medical or other reasons' or because they have been directed off the 
mainstream site by their head teacher. It is thought that the latter reason is the more likely explanation for the significant numbers placed in AP year on year. It has also been shown that the characteristics of pupils directed off the school site are broadly in line with those who have historically experienced high levels of permanent exclusion from school. The notable exceptions are pupils with an EHC plan or statement of SEN and looked after children and young people. Both of these groups are present in the AP population at a far higher rate than they are in the PEx data. This is particularly the case for children and young people in the care of their local authority who experience PEx at around twice the rate for all pupils but placement into AP at over 29 times the rate for all pupils. It has been argued that this significant over-representation means head teachers could do more to keep school as a place of stability for pupils in care. The case has also been made for better accountability. The simplest solution to this would be to expand the current reporting on exclusions to include the use of alternative population and the experiences of children in care 9 .

In addition to better national reporting there is also local and school level accountability to consider. Schools already have duties in relation to AP record keeping (DfE, 2013). A simple move to better accountability could involve a requirement for schools to provide the data they collect during their use of AP to their LA who would then have a duty to collate an annual report on AP in their local area. This could be undertaken as part of the annual school census. There would of course be complexities where schools have 'academy' or 'free school' status and therefore report their census data straight to the DfE, however returning this information to LAs would unlikely be a complex process. Indeed this proposal reflects the direction of travel set out in recent the government White Paper (DfE, 2016a) of a role for LAs in the encouragement and maintenance of positive AP in their locality.

\footnotetext{
${ }^{9}$ It would be better still to also include 'children in need' and those adopted from care.
} 
The final point to make is that although this article has argued for clearer and more consistent reporting of alternative provision on a number of occasions issues which relate to alternative provision have been outside the remit of the argument put forward here. Future research could usefully consider the experiences of children in care attending alternative provision settings; the use of managed moves across the national schooling system; and, using emerging definitions of exclusion as education outside the mainstream norms (Clay and Thomas, 2014 and Bennett, 2017), the extent to which schools are using seclusion ${ }^{10}$ and the nature of this use. As noted above, a focus on the complex dynamics of inclusion and exclusion is an appropriate route to developing inclusive practice. This is the underlying intention of the author in writing this paper, to focus on the experiences of children and young people marginalised and excluded from mainstream schooling so as to move in the direction of a more inclusive schooling system.

\footnotetext{
${ }^{10}$ Also known as isolation and internal exclusion this practice removes pupils form the mainstream classroom but keeps them on the mainstream site. With the exception of Barker et al. (2010) this topic lacks any significant research.
} 


\section{References}

Barker, J., Alldred, P., Watts, M. \& Dodman, H. (2010) 'Pupils or prisoners? Institutional geographies and internal exclusion in UK secondary schools', Area, 42 (3) pp. 378-386. Available at: http://onlinelibrary.wiley.com/doi/10.1111/j.1475-4762.2009.00932.x/pdf (Accessed: $13^{\text {th }}$ April 2017)

Barrow, G. (2000) ' No One’s Tole Me to F**k Off!': Four Years Working with Disaffected Year 11 Pupils (without a PRU)', Pastoral Care, 18 (1) pp.3-8. Available at:

http://onlinelibrary.wiley.com/doi/10.1111/1468-0122.00147/abstract (Accessed: $7^{\text {th }}$ March 2016)

Bennett, T. (2017) 'Creating a Culture: How school leaders can optimise behaviour', Department for Education. Available at:

https://www.gov.uk/government/uploads/system/uploads/attachment_data/file/602487/Tom Bennett_Independent_Review_of_Behaviour_in_Schools.pdf (Accessed: 13 ${ }^{\text {th }}$ April 2017)

Berridge, D. (2017) 'The education of children in care: Agency and resilience', Children and Youth Services Review. Available at:

http://www.sciencedirect.com/science/article/pii/S0190740916305709 (Accessed: $13^{\text {th }}$ April 2017)

Bollmer, J.B., Bethel, J., Garrison-Mogren, R., \& Brauen, M. (2007) Using the risk ratio to assess racial/ethnic disproportionality in special education at the school-district level', The Journal of Special Education, 41(3), pp.186-198. Available at: 
http://sed.sagepub.com/content/41/3/186.full.pdf+html (Accessed: $9^{\text {th }}$ March 2016)

Clark, C., Dyson, A., Millward, A. \& Robson, S. (1999) 'Theories of Inclusion, Theories of Schools: Deconstructing and Reconstructing the 'Inclusive School', British Educational Research Journal, 25 (2), pp. 157-177. Available at: http://www.jstor.org/stable/1501631 (Accessed: $13^{\text {th }}$ April 2017)

Clay, D. \& Thomas, A. (2014) 'Review of military ethos alternative provision projects', Department for Education. Available at:

https://www.gov.uk/government/publications/military-ethos-alternative-provision-projectsreview (Accessed: $9^{\text {th }}$ March 2016)

Cook, L. (2005) 'School without walls: Reconnecting the disconnected at 14+', Support for Learning, 20 (2), pp.90-95. Available at: http://onlinelibrary.wiley.com/doi/10.1111/j.02682141.2005.00367.x/pdf (Accessed: $9^{\text {th }}$ March 2016)

Cullen, K. \& Monroe, J. (2010) 'Using positive relationships to engage the disengaged: An educational psychologist-initiated project involving professional sports input to a Pupil Referral Unit', Educational \& Child Psychology, 27 (1), pp.64-78. Available at: http://www.wellbeingaustralia.com.au/wba/pdfs/ecp27_1/ECP27_1\%20Cullen\%20Monroe.p df (Accessed: $9^{\text {th }}$ March 2016)

D’Arcy, K. (2014) 'Travellers and Home Education - Safe spaces and inequality'. London: Trentham and IOE Press. 
DCSF, (2008) 'Back on Track'. Available at:

https://www.gov.uk/government/uploads/system/uploads/attachment_data/file/328241/Back on_Track.pdf (Accessed: $9^{\text {th }}$ March 2016)

de Castella, T. (2011) 'Back to education', Children \& Young People Now, pp.18-19. Available at: http://www.cypnow.co.uk/cyp/feature/1050423/back-education (Accessed: $9^{\text {th }}$ March 2016)

DfE, (2011) 'Schools, Pupils and their Characteristics: January 2011'. Available at: https://www.gov.uk/government/statistics/schools-pupils-and-their-characteristics-january2011 (Accessed: 19th July 2017)

DfE, (2012a) 'Permanent and fixed-period exclusions in England: 2010 to 2011'. Available at: https://www.gov.uk/government/statistics/permanent-and-fixed-period-exclusions-fromschools-in-england-academic-year-2010-to-2011 (Accessed: 19th July 2017)

DfE, (2012b) 'Schools, Pupils and their Characteristics: January 2012'. Available at: https://www.gov.uk/government/statistics/schools-pupils-and-their-characteristics-january$\underline{2012}$ (Accessed: 19th July 2017)

DfE, (2013a) 'Alternative Provision: Statutory guidance for local authorities'. Available at: https://www.gov.uk/government/uploads/system/uploads/attachment_data/file/268940/alterna tive _provision_statutory_guidance_pdf_version.pdf (Accessed: $9^{\text {th }}$ March 2016)

DfE, (2013b) 'Permanent and fixed-period exclusions in England: 2011 to 2012'. Available 
at: https://www.gov.uk/government/statistics/permanent-and-fixed-period-exclusions-fromschools-in-england-2011-to-2012-academic-year (Accessed: 19th July 2017)

DfE, (2013c) 'Schools, Pupils and their Characteristics: January 2013'. Available at: https://www.gov.uk/government/statistics/schools-pupils-and-their-characteristics-january$\underline{2013}$ (Accessed: 19th July 2017)

DfE, (2014a) 'Outcomes for children looked after by local authorities in England, 31 March 2013'. Available at:

https://www.gov.uk/government/uploads/system/uploads/attachment_data/file/264385/SFR50 2013 Text.pdf (Accessed: 19th July 2017)

DfE, (2014b) 'Permanent and fixed-period exclusions in England: 2012 to 2013'. Available at: https://www.gov.uk/government/statistics/permanent-and-fixed-period-exclusions-inengland-2012-to-2013 (Accessed: 19th July 2017)

DfE, (2014c) 'Schools, Pupils and their Characteristics: January 2014'. Available at: https://www.gov.uk/government/statistics/schools-pupils-and-their-characteristics-january$\underline{2014}$ (Accessed: 19th July 2017)

DfE, (2015a) 'Outcomes for children looked after by local authorities in England, 31 March 2014'. Available at:

https://www.gov.uk/government/uploads/system/uploads/attachment_data/file/384781/Outco mes_SFR49_2014_Text.pdf (Accessed: 19th July 2017) 
DfE, (2015b) 'Permanent and fixed-period exclusions in England: 2013 to 2014'. Available at: https://www.gov.uk/government/statistics/permanent-and-fixed-period-exclusions-inengland-2013-to-2014 (Accessed: 19th July 2017)

DfE, (2015c) 'Schools, Pupils and their Characteristics: January 2015'. Available at: https://www.gov.uk/government/statistics/schools-pupils-and-their-characteristics-january$\underline{2015}$ (Accessed: 19th July 2017)

DfE, (2016a) 'Educational Excellence Everywhere'. Available at: https://www.gov.uk/government/uploads/system/uploads/attachment_data/file/508447/Educat ional_Excellence Everywhere.pdf (Accessed: 22 ${ }^{\text {nd }}$ August 2016)

DfE, (2016b) 'Absence and exclusions additional analysis for pupils with special educational needs (SEN)'. Available at: https://www.gov.uk/government/uploads/system/uploads/attachment_data/file/495651/SEN Absence_Exclusions_ad_hoc_release_v4.pdf (Accessed 23rd August 2016)

DfE, (2016c) 'Outcomes for children looked after by local authorities in England, 31 March 2015'. Available at: https://www.gov.uk/government/uploads/system/uploads/attachment_data/file/509965/SFR11 2016_SFRText.pdf (Accessed 23rd August 2016)

DfE, (2016d) 'Permanent and fixed-period exclusions in England: 2014 to 2015'. Available at: https://www.gov.uk/government/statistics/permanent-and-fixed-period-exclusions-inengland-2014-to-2015 (Accessed: 19th July 2017) 
DfE, (2016e) 'Schools, Pupils and their Characteristics: January 2016'. Available at: https://www.gov.uk/government/statistics/schools-pupils-and-their-characteristics-january$\underline{2016}$ (Accessed: 19th July 2017)

Gazeley, L. (2010) 'The role of school exclusion processes in the re-production of social and educational disadvantage', British Journal of Educational Studies, 58 (3), pp.293-309. Available at: http://www.tandfonline.com/doi/abs/10.1080/00071000903520843\#.VuAAM0BK23g (Accessed: $9^{\text {th }}$ March 2016)

Gazeley, L., Marrable, T., Brown, C. \& Boddy, J. (2013) Reducing inequalities in school exclusion: Learning from good practice, University of Sussex. Available at: $\underline{\text { http://sro.sussex.ac.uk/44751/ (Accessed: } 9^{\text {th }} \text { March 2016) }}$

Gleeson, D. (1992) 'School attendance and truancy: a socio-historical account', The Sociological Review, 40 (3), pp.437-490. Available at: http://onlinelibrary.wiley.com/doi/10.1111/j.1467954X.1992.tb00398.x/abstract?userIsAuthenticated=false \&deniedAccessCustomisedMessage $=\left(\right.$ Accessed: $9^{\text {th }}$ March 2016)

Gorard, S. (2003) 'Quantitative Methods in Social Science: The role of numbers made easy'. London: Continuum.

Kendall, S., Kinder, K., Halsey, K., Fletcher-Morgan, C., White, R. \& Brown, C. (2003) An 
Evaluation of Alternative Education Initiatives, National Foundation for Educational Research. Available at:

http://webarchive.nationalarchives.gov.uk/20130401151715/http://www.education.gov.uk/pu blications/eOrderingDownload/RR403.pdf (Accessed: $9^{\text {th }}$ March 2016)

Kendall, S., Wilkin, A., Kinder, K., Gulliver, C., Harland, J., Martin, K. \& White, R. (2007) Effective Alternative Provision, National Foundation for Educational Research. Available at: https://www.gov.uk/government/uploads/system/uploads/attachment_data/file/222367/DCSF -RW002.pdf (Accessed: $9^{\text {th }}$ March 2016)

Lindsay, G. (2007) 'Educational psychology and the effectiveness of inclusive education/mainstreaming', British Journal of Educational Psychology, 77, pp. 1-24. Available at: http://onlinelibrary.wiley.com/doi/10.1348/000709906X156881/pdf (Accessed: $13^{\text {th }}$ April 2017)

Malberg, N.T. (2008) 'Refusing to be excluded: Finding ways of integrating psychotherapeutic modalities to the emerging needs of a pupil referral unit', Journal of Child Psychotherapy, 34 (1), pp.101-110. Available at:

http://www.tandfonline.com/doi/pdf/10.1080/00754170801895854 (Accessed: $9^{\text {th }}$ March 2016)

Malcolm, A. (2015) 'Alternative provision as an educational option: understanding the experiences of excluded young people'. Professional Doctorate Thesis. University of Bedfordshire. Available at: http://hdl.handle.net/10547/608337 (Accessed: 13 ${ }^{\text {th }}$ April 2017) 
McCluskey, G., Lloyd, G., Riddell, S., Weedon, E., \& Fordyce, M. (2013) Evaluation of education provision for children and young people educated outside the school setting, Welsh Government Social Research. Available at:

http://www.docs.hss.ed.ac.uk/education/creid/Reports/31_WAG_EOTAS FinalRpt.pdf (Accessed: $9^{\text {th }}$ March 2016)

McCluskey, G., Riddell, S. \& Weedon, E. (2015) 'Children's rights, school exclusion and alternative educational provision', International Journal of Inclusive Education, 19 (6), pp595-607. Available at:

http://www.tandfonline.com/doi/full/10.1080/13603116.2014.961677 (Accessed: $9^{\text {th }}$ March 2016)

McLoughlin, C. (2010) 'Concentric circles of containment: a psychodynamic contribution to working in pupil referral units', Journal of Child Psychotherapy, 36 (3), pp225-239. Available at: $\underline{\mathrm{http}}$ ://dx.doi.org/10.1080/0075417X.2010.524772 (Accessed: $13^{\text {th }}$ April 2017) Meo, A. \& Parker, A. (2004) 'Teachers, teaching and educational exclusion: Pupil referral units and pedagogic practice', International Journal of Inclusive Education, 8 (1), pp.103120. Available at: http://www.tandfonline.com/doi/pdf/10.1080/1360311032000159465 (Accessed: $9^{\text {th }}$ March 2016)

Office for the Children's Commissioner (2012) 'They never give up on you'. Available at: http://www.childrenscommissioner.gov.uk/sites/default/files/publications/They\%20never\%20 give $\% 20$ up $\% 20$ on $\% 20$ you $\% 20$ final $\% 20$ report.pdf (Accessed: $19^{\text {th }}$ April 2017) 
Ofsted (2004) 'Out of school: A survey of the educational support and provision for pupils not in school'. London: Ofsted.

Ofsted, (2011) 'Alternative provision'. Available at:

https://www.gov.uk/government/uploads/system/uploads/attachment_data/file/413554/Altern ative provision.pdf (Accessed: $9^{\text {th }}$ March 2016)

Ofsted (2013) 'Pupils missing out on education'. Available at:

http://dera.ioe.ac.uk/18825/1/Pupils\%20missing\%20out\%20on\%20education.pdf (Accessed: $9^{\text {th }}$ March 2016)

Ofsted (2014) 'Alternative provision: A report on the findings from the first year of a threeyear survey'. Available at:

https://www.gov.uk/government/uploads/system/uploads/attachment_data/file/498659/Altern ative provision report on findings from the first year.pdf (Accessed: $9^{\text {th }}$ March 2016)

Paget, A., Parker, C., Henley, W., Heron, J., Ford, T. \& Emond, A. (2015) 'Which children and young people are excluded from school? Findings from the Avon Longitudinal Study of Parents and Children (ALSPAC)', Lancet, 385 (1), pp. S76. Available at: http://doi.org/10.1016/S0140-6736(15)60391-9 (Accessed: 13 ${ }^{\text {th }}$ April 2017)

Parsons, C. (1999) 'Education, Exclusion and Citizenship'. London: Routledge.

Parsons, C. (2008) 'Race relations legislation, ethnicity and disproportionality in school exclusions in England', Cambridge Journal of Education, 38 (3), pp.401-419. Available at: 
http://www.tandfonline.com/doi/abs/10.1080/03057640802299668 (Accessed: $19^{\text {th }}$ July 2017)

Riley, K., Ellis, S., Weinstock, W., Tarrant, J. \& Hallmond, S. (2006) 'Re-engaging pupils in learning: insights for policy and practice', Improving Schools, 9 (1), pp.17-31. Available at: http://imp.sagepub.com/content/9/1/17.short?rss=1\&ssource $=\mathrm{mfc}$ (Accessed: $9^{\text {th }}$ March 2016)

Russell, L. \& Thomson, P. (2011) 'Girls and gender in alternative education provision’, Ethnography and Education, 6 (3), pp.293-308. Available at:

http://www.tandfonline.com/doi/full/10.1080/17457823.2011.610581 (Accessed: $9^{\text {th }}$ March 2016)

Smith, E. (2009) 'What can secondary data analysis tell us about school exclusions in England?', International Journal of Research \& Method in Education, 32 (1), pp.89-101. Available at: http://www.tandfonline.com/doi/abs/10.1080/17437270902749304 (Accessed: $19^{\text {th }}$ July 2017)

Taylor, C. (2012) 'Improving Alternative Provision'. Available at:

https://www.gov.uk/government/uploads/system/uploads/attachment_data/file/180581/DFE00035-2012.pdf (Accessed: $9^{\text {th }}$ March 2016)

Terry, A. \& Walls, J. (2014) 'Finding for Pupil Referral Services / Alternative Provision', North Yorkshire County Council. Available at:

https://www.whatdotheyknow.com/request/238919/response/643233/attach/4/ITEM\%206\%2 
0Alternative\%20Provision.pdf (Accessed: $13^{\text {th }}$ April 2017)

Thomson, P. \& Russell, L. (2007) Mapping the alternatives to permanent exclusion, Joseph Rowntree Foundation. Available at:

http://www.jrf.org.uk/sites/default/files/jrf/migrated/files/2073-exclusion-alternativeseducation.pdf (Accessed: $9^{\text {th }}$ March 2016)

Thomson, P. \& Russell, L. (2009) 'Data, data everywhere - but not all the numbers that count? Mapping alternative provisions for students excluded from school', International Journal of Inclusive Education, 13 (4), pp. 423-438. Available at:

http://www.tandfonline.com/doi/abs/10.1080/13603110801983264\#.VuAw-UBK23g (Accessed: $9^{\text {th }}$ March 2016)

Thomson, P. \& Pennacchia, J. (2015) 'Hugs and behaviour points: Alternative education and the regulation of 'excluded' youth', International Journal of Inclusive Education, 20 (6), pp. 622-640. Available at: http://dx.doi.org/10.1080/13603116.2015.1102340 (Accessed: $19^{\text {th }}$ April 2017)

Visser, J., Daniels, H. \& Macnab, N. (2005) 'Missing', Emotional and Behavioural Difficulties, 10 (1), pp. 43-54. Available at: http://dx.doi.org/10.1080/1363275205050884 (Accessed: $13^{\text {th }}$ April 2017)

Watling, R. (2004) 'Helping them out', Emotional and Behavioural Difficulties, 9 (1), pp. 8-27. Available at: http://dx.doi.org/10.1177/1363275204038258 (Accessed: $13^{\text {th }}$ April 2017) 
White, R., Martin, K. \& Jeffes, J. (2012) The back on track alternative provision pilots, National Foundation for Educational Research. Available at:

http://www.nfer.ac.uk/publications/APIZ01/APIZ01 home.cfm (Accessed: $9^{\text {th }}$ March 2016)

Youdell, D. (2003) 'Identity Traps or How Black Students Fail: the interactions between biographical, sub-cultural, and learner identities', British Journal of Sociology of Education, 24 (1), pp.3-20. Available at: http://www.tandfonline.com/doi/pdf/10.1080/01425690301912 (Accessed: $9^{\text {th }}$ March 2016) 
Table 1 - Pupils attending PRUs and alternative provision 2011 - 2016. Population figures are for January of the year in question, Exclusions data cover the full academic year in which this January falls.

\begin{tabular}{|c|c|c|c|c|c|c|c|}
\hline Year & $\begin{array}{l}\text { Pupils } \\
\text { in } \\
\text { PRUs }\end{array}$ & $\begin{array}{l}\text { Pupils in } \\
\text { PRUs who } \\
\text { are dual } \\
\text { registered } \\
\text { with their } \\
\text { main } \\
\text { registration } \\
\text { elsewhere }\end{array}$ & $\begin{array}{l}\text { All } \\
\text { pupils } \\
\text { in } \\
\text { PRUs }\end{array}$ & $\begin{array}{l}\text { Pupils } \\
\text { in AP }\end{array}$ & $\begin{array}{l}\text { All } \\
\text { pupils } \\
\text { in AP } \\
\text { and } \\
\text { PRUs }\end{array}$ & $\begin{array}{l}\text { Pupils } \\
\text { Permanently } \\
\text { Excluded }\end{array}$ & $\begin{array}{l}\text { Pupils } \\
\text { excluded } \\
\text { on a fixed } \\
\text { term basis } \\
\text { for } 6 \text { or } \\
\text { more } \\
\text { days }\end{array}$ \\
\hline 2011 & 14,050 & 9,125 & 23,175 & 23,020 & 46,195 & 5,080 & 9,300 \\
\hline 2012 & 13,495 & 9,145 & 22,640 & 22,130 & 44,770 & 5,170 & 8,020 \\
\hline 2013 & 12,950 & 9,425 & 22,375 & 22,205 & 44,580 & 4,630 & 6,790 \\
\hline 2014 & 12,895 & 9,685 & 22,580 & 20,215 & 42,795 & 4,950 & 6,620 \\
\hline 2015 & 13,585 & 10,205 & 23,790 & 20,503 & 44,293 & 5,800 & 7,350 \\
\hline 2016 & 15,015 & 10,424 & 25,439 & 22,032 & 47,471 & & \\
\hline $\begin{array}{l}\text { Average } \\
2011- \\
2015\end{array}$ & 13665 & 9668 & 23333 & 21684 & 45017 & 4272 & 6347 \\
\hline
\end{tabular}

Source: SPC 2011 through to 2016 and PFPEE 2010/11 through to 2014/15. 
Table 2 - Average number of pupils in AP between 2011 and 2015 with analysis of numbers who are placed by circumstances for placement.

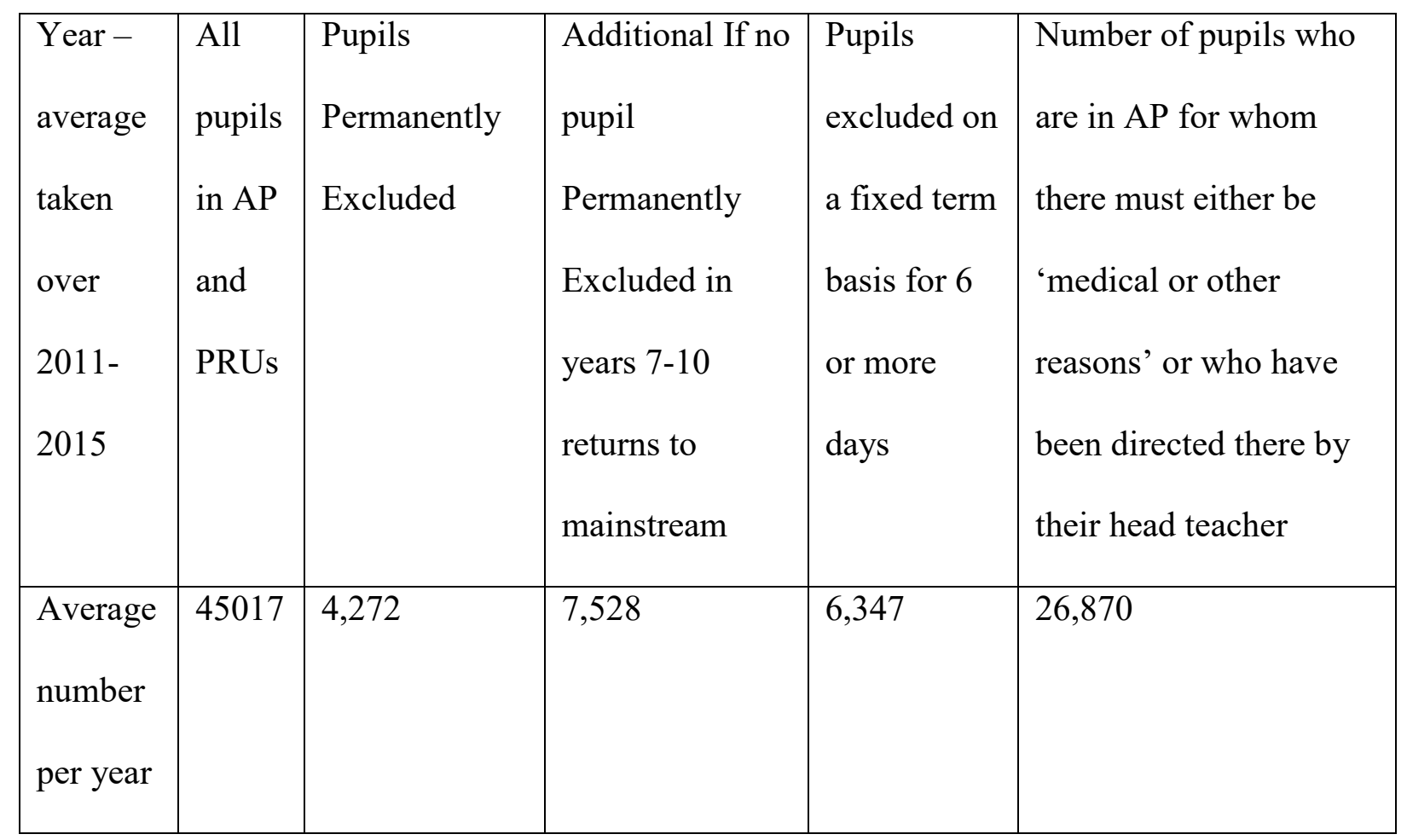

Source: SPC 2011 through to 2016 and PFPEE 2010/11 through to 2014/15. 
Table 3 - Over-represented groups experiencing permanent exclusion and placement into alternative provision. Averages over the years 2011/12 - 2013/14

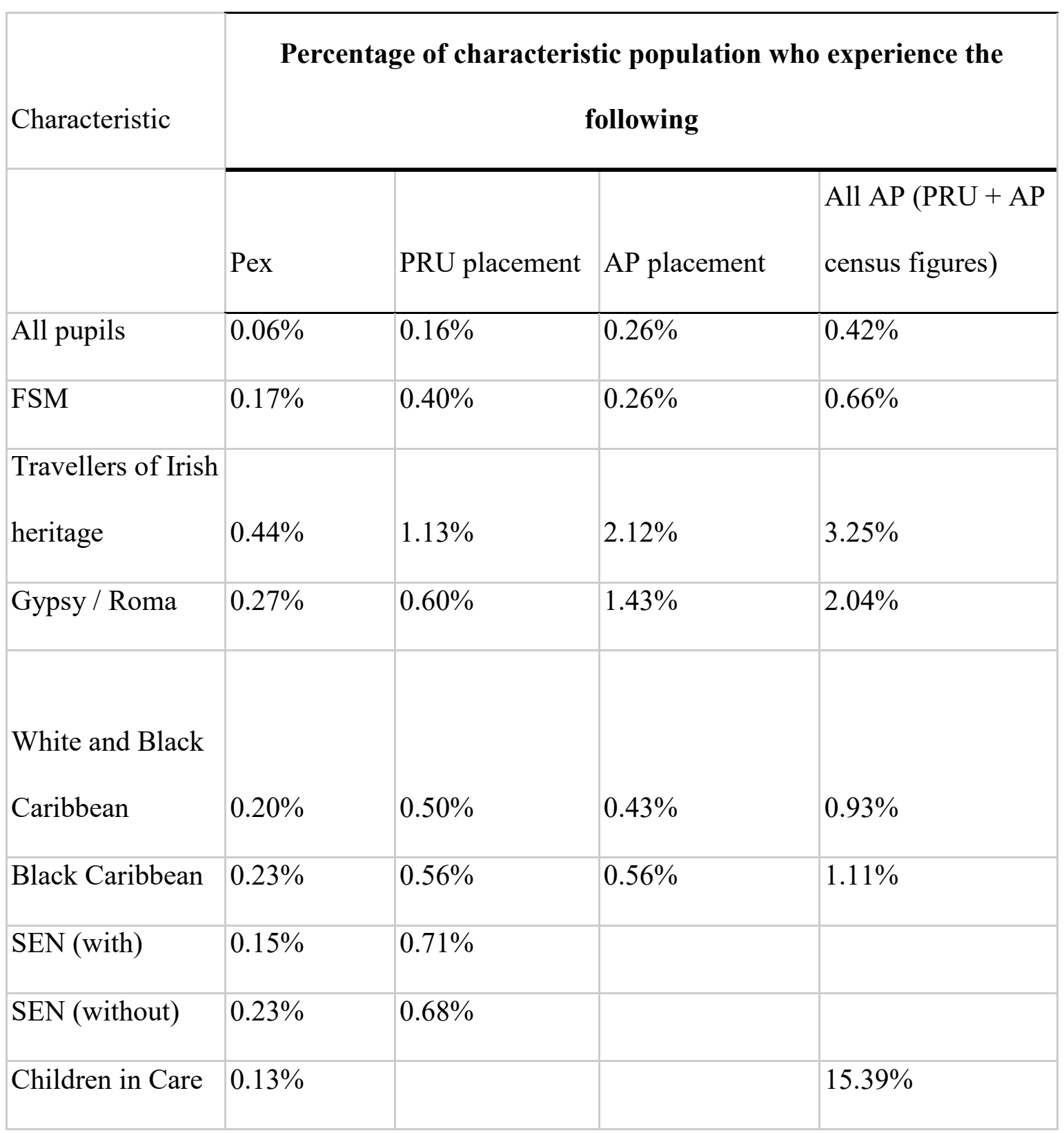

Source: SPC 2012, 2013, 2014 and 2016; PFPEE 2011/12 through to 2013/14; OCLALAE 2013, 2014 and 2015 and FOI response. 
Table 4 - Over-representation in permanent exclusion and population statistics

\begin{tabular}{|c|c|c|c|c|}
\hline \multirow[t]{2}{*}{ Characteristic } & \multicolumn{4}{|c|}{ Rate of overrepresentation } \\
\hline & Pex & $\begin{array}{l}\text { PRU } \\
\text { placement }\end{array}$ & AP placement & $\begin{array}{l}\text { All AP (PRU + AP } \\
\text { census figures })\end{array}$ \\
\hline FSM & 2.82 & 2.52 & 0.98 & 1.57 \\
\hline $\begin{array}{l}\text { Travellers of Irish } \\
\text { heritage }\end{array}$ & 6.07 & 5.83 & 6.87 & 6.47 \\
\hline Gypsy / Roma & 3.75 & 3.09 & 4.62 & 4.02 \\
\hline $\begin{array}{l}\text { White and Black } \\
\text { Caribbean }\end{array}$ & 2.67 & 2.54 & 1.41 & 1.85 \\
\hline Black Caribbean & 3.15 & 2.85 & 1.81 & 2.22 \\
\hline $\begin{array}{l}\text { SEN (with statem } \\
\text { EHC plan) }\end{array}$ & 2.57 & 4.49 & & \\
\hline $\begin{array}{l}\text { SEN (without sta } \\
\text { EHC plan) }\end{array}$ & 3.86 & 4.25 & & \\
\hline Children in Care & 1.98 & & & 29.71 \\
\hline
\end{tabular}

Source: SPC 2012, 2013, 2014 and 2016; PFPEE 2011/12 through to 2013/14; OCLALAE 2013, 2014 and 2015 and FOI response. 
Table 5 - Comparing permanent and fixed period exclusion statistics

\begin{tabular}{|l|l|l|}
\hline $2013 / 14$ & Permanent exclusion & Fixed period exclusion \\
\hline Looked after children & $0.13 \%$ & $10.25 \%$ \\
\hline Children in need & $0.17 \%$ & $6.54 \%$ \\
\hline SEN with statement & $0.15 \%$ & $6.42 \%$ \\
\hline SEN without statement & $0.25 \%$ & $5.17 \%$ \\
\hline
\end{tabular}

Source: PFPEE 2013/14 and OCLALAE 2015 